\title{
Kejadian Bullyng Pada Remaja dan Faktor yang Berhubungan
}

\author{
Rosmin Ilham ${ }^{1}$, Rachmawaty D. Hunawa ${ }^{2}$, Fadillah Iralisty Hunta ${ }^{3}$ \\ 1,2,3 Program Studi Ilmu Keperawatan Universitas Negeri Gorontalo \\ E-mail: rosmin_ilham@yahoo.com
}

\begin{abstract}
Abstrak
Bullying merupakan perilaku agresif seseorang atau sekelompok orang yang dilakukan secara berulang terhadap orang atau sekelompok orang lain yang lebih lemah untuk menyakiti korban secara fisik maupun mental. Banyak faktor yang dapat berhubungan dengan kejadian bullying antara lain yaitu faktor jenis kelamin, teman sebaya dan media social. Tujuan penelitian ini adalah menganalisa dan menidentifikasi faktor-faktor yang berhubungan dengan kejadian bullying pada remaja di SMP N 3 Gorontalo. Metode yang digunakan yaitu menggunakan desain penelitian cross sectional. Populasinya adalah seluruh siswa kelas VII di SMP N 3 Gorontalo. Dan instrumennya yaitu menggunakan data demografi dan kuesioner. Hasil penelitian ini menggunakan uji fisher's exact test. Didapatkan bahwa yang paling banyak melakukan bullying yaitu yang berjenis kelamin perempuan 78 responden (51\%), teman sebaya dalam kategori sedang 93 responden (60.8\%), dan media sosial dalam kategori tinggi 112 responden (73.2\%). Kesimpulan dari penelitian ini adalah ada hubungan antara faktor jenis kelamin $(0,034)$, teman sebaya $(0,039)$, dan media sosial $(0,028)$ terhadap kejadian bullying pada remaja di SMP N 3 Gorontalo.
\end{abstract}

\section{Kata Kunci : Bullying, remaja}

\begin{abstract}
Bullying is the aggressive behavior of a person or group of people which is repeated against another person or group of weaker people to hurt the victim physically or mentally. Many factors can be associated with the incidence of bullying, including gender, peer and social media factors. The purpose of this study was to analyze and identify factors related to the incidence of bullying in adolescents at SMP N 3 Gorontalo. The method used is to use a cross sectional research design. The population was all grade VII students at SMP N 3 Gorontalo. And the instruments are using demographic data and questionnaires. The results of this study used fisher's exact test. It was found that the most bullying was female, 78 respondents $(51 \%)$, peers in the medium category of 93 respondents $(60.8 \%)$, and social media in the high category of 112 respondents $(73.2 \%)$. The conclusion of this study is that there is a relationship between gender (0.034), peer (0.039), and social media (0.028) on the incidence of bullying in adolescents at SMP N 3 Gorontalo.
\end{abstract}

Keywords: Bullying, teenagers

\section{Pendahuluan}

Remaja merupakan seorang individu yang berada pada fase dimana mereka mulai mencari jati diri, biasanya berada pada rentang usia antara 10-19 tahun. Di fase ini, remaja akan berusaha beradaptasi dengan perubahan yang terjadi baik dalam aspek biologis maupun psikologis dalam perkembangan remaja (WHO, 2014).

Pada masa remaja terjadi perkembangan kepercayaan diri yang berasal dari konsep diri. Masa remaja memiliki rasa egosentrisme yang tinggi, hal ini dapat memicu terjadinya penyimpangan perilaku atau yang biasa disebut dengan bullying. Fenomena perilaku bullying merupakan salah satu bagian dari kenakalan remaja di masa-masa remaja. Akhir-ahir ini maraknya kasus bullying justru bertempat di sekolah. Sekolah yang harusnya menjadi tempat bagi anak untuk menimbang ilmu dan membentuk karakter pribadi yang 
sifatnya positif ternyata malah menjadi lokasi praktek bullying (Sripurwaningsih, 2017).

Bullying merupakan perilaku agresif berupa penyalahgunaan kekuatan /kekuasaan yang dilakukan oleh seseorang/sekelompok kepada orang lain, sehingga dapat mengakibatkan kerusakan fisik, psikologis dan sosial secara berulang, yang sering terjadi di sekolah dan tempat lain di mana anak berkumpul, termasuk juga media sosial (WHO, 2018).

Fenomena seputar perilaku bullying sudah terjadi sejak tahun 1960 akhir atau sekitar awal permulaan 1970 di sweden, (Provis, 2012). Fenomena bullying pertama kali diteliti di sekolah-sekolah di Norwegia dan Swedia oleh seorang peneliti berkebangsaan Norwegia. Hasilnya menunjukan bahwa kurang lebih 7\% dari siswa di dua negara tersebut terlibat dalam bullying, dan antara 5\% dan 15\% siswa pernah menjadi korban bullying. Penelitian serupa juga pernah dilakukan di beberapa negara lain seperti Austria, Kanada, Inggris, Italia, dan Amerika Serikat. Dan di negara Asia sendiri bullying telah banyak diteliti di Jepang, Korea, China Malaysia, Singapura, Filiphina, Dan Indonesia (Moon et al 2008, dalam Darmawan 2017).

Di salah satu riset yang telah dilakukan oleh LSM Plan International dan
International Center for Research on Women (ICRW) didapatkan fakta mengejutkan terkait kekerasan anak di sekolah. Di tingkat Asia, kasus bullying yang terjadi pada siswa di sekolah mencapai angka 70\% (Qodar, 2015). Selain itu, hasil riset yang dilakukan oleh National Association of School Psychologist menunjukkan bahwa lebih dari 160.000 remaja di Amerika Serikat bolos sekolah setiap hari karena takut di bullying (Sari, 2010 dalam Puluhulawa, 2018).

Indonesia juga terlibat dalam kasus bullying, dibuktikan dengan hasil survei dari yayasan SEJIWA (Semai Jiwa Amini). Peneliitian SEJIWA pada tahun 2008 tentang kekerasan bullying di tiga kota besar di Indonesia, yaitu Yogyakarta, Surabaya, dan Jakarta mencatat terjadinya tingkat kekerasan sebesar $67,9 \%$ di tingkat Sekolah Menengah Atas (SMA) dan 66,1\% di tingkat Sekolah Menengah Pertama (SMP). Kekerasan yang dilakukan sesama siswa dengan kategori tertinggi yaitu kekerasan psikologis berupa pengucilan. Peringkat kedua ditempati kekerasan verbal seperti mengejek dan terakhir kekerasan fisik (Wiyani, 2012).

Di Gorontalo sendiri juga sudah banyak terjadi kasus bullying. Informasiinformasi tersebut sudah didapatkan melalui media salah satunya kabar harian 
Gorontalo. Kasus kekerasan yang dilakukan oleh delapan orang senior kepada junior, di sekolah lain juga ditemukan kasus serupa yaitu penindasan yang dilakukan oleh kakak kelas kepada adik kelasnya sampai mempengaruhi beberapa organ vital dari korban. Korbankorban yang bersangkutan bolos sekolah bahkan sampai ada yang dirawat di rumah sakit (Harian Banthayo.ID, Gorontalo 2019).

Faktor yang berhubungan dengan perilaku bullying pada remaja disekolah, antara lain yaitu jenis kelamin, teman sebaya, media sosial, peringkat kelas, dan kepribadian. Faktor jenis kelamin berpengaruh sebab berbeda aktivitas yang dilakukan jika disekolah, laki-laki cenderung lebih banyak adu fisik jika berkelahi seperti saling pukul, saling tendang bahkan sampai tawuran. Sedangkan, anak perempuan lebih cenderung untuk berkumpul atau membentuk geng dan bercakap- cakap seperti bergosip, menggunjing, menyindir dan lain sebagainya. Di kedua perbedaan ini menunjukan bahwa kejadian bullying yang akan timbul menunjukkan dua sisi yang berbeda. Faktor teman sebaya juga berhubungan dengan kejadian bullying. Remaja membutuhkan dorongan dari teman-teman sepergaulan dengan umur yang sama. Pada masa remaja hubungan persahabatan serta dukungan sebaya sangatlah penting sehingga ada kecenderungan mandiri dan tidak tergantung pada orang tua. Hal ini menyebabkan seorang remaja akan berusaha dekat dengan teman- temannya untuk mendapatkan dukungan disetiap perbuatannya. Dukungan ini biasanya diberikan pada individu yang menunjukkan kekuatan dan kekuasaan di lingkungannya, sehingga ditakuti oleh teman-temannya. Namun, ada juga beberapa yang melakukan bullying dalam usaha untuk membuktikan bahwa mereka bisa masuk dalam kelompok tertentu, meskipun mereka sendiri merasa tidak nyaman dengan perilaku tersebut. Akan tetapi, hubungan teman sebaya yang tidak sehat akan berdampak signifikan pada resiko terjadinya perilaku bullying (Hong \& Espelage, 2012).

Faktor media sosial dianggap berhubungan erat dengan bullying karena masa remaja masih hangat- hangatnya dengan perkembangan teknologi yang terjadi. Maka tidak dapat dipungkiri semua informasi dapat terhubung melalui media, tontonan-tontonan yang tidak sesuai dengan batasan usia dapat mempengaruhi seorang remaja untuk meniru apa yang ditotonya ke dalam lingkungan sekolah (Jannatung, 2018). 
Penelitian yang dilakukan oleh

Putri (2015) menunjukan bahwa faktor teman sebaya ada hubungan yang signifikan dengan perilaku bullying pada remaja. Teman sebaya disekolah biasanya dianggap sebagai partner yang saling mendukung satu sama lain, sehingga sebagian siswa yang melakukan perilaku bullying di sekolah disebabkan oleh dorongan teman-temannya. Menurut putri, untuk mencegah terjadinya kejadian yang serupa maka pihak sekolah diharapkan lebih memperketat pengawasan terhadap siswa- siswanya, selain itu, sekolah juga diharapkan terus meningkatkan pelaksanaan kegiatan pembinaan.

Berdasarkan survey awal yang dilakukan di SMP N 3 Gorontalo pada tgl 12 februari 2020, hasil wawancara oleh 6 siswa didapatkan4 siswa laki-laki mengatakan bullying yang sering terjadi yaitu saling ejek mengejek sehingga sampai terjadi perkelahian. Dari 2 siswa perempuan menyatakan bahwa kasus bullying diawali oleh miskomunikasi, salah presepsi, sehingga terjadi adu fisik. Berdasarkan wawancara dengan guru BK bahwa kasus bullying yang berat baru 1 kali yaitu kasus penganiyayaan sehingga organ vital korban terganggu. Dari kejadian ini sekolah telah mengambil tindakan berupa mengeluarkan pelaku bullying dari sekolah.

Berdasarkan latar belakang yang telah dipaparkan, maka peneliti tertarik untuk mengetahui faktor- faktor yang berhubungan dengan kejadian bullying pada remaja SMP Negeri 3 Gorontalo.

\section{Metode}

Penelitian ini menggunakan desain penelitian analitik korelasional dengan pendekatan cross sectional yaitu rancangan penelitian dengan melakukan pengukuran dan pengamatan pada waktu yang bersamaan. Populasi dalam penelitian ini adalah seluruh siswa kelas VII yang sekolah di SMP N 3 Gorontalo berjumlah 153 siswa. Sampel pada penelitian ini adalah seluruh siswa kelas VII yang sekolah di SMP N 3 Gorontalo berjumlah

153 siswa. Teknik pengambilan sampel dalam penelitian ini adalah total sampling. Pengumpulan data menggunakan data demografi dan kuesioner pernyataan teman sebaya, media sosial dan bullying.

\section{Hasil}


pISSN: 2654-2927, eISSN: 2656-4653

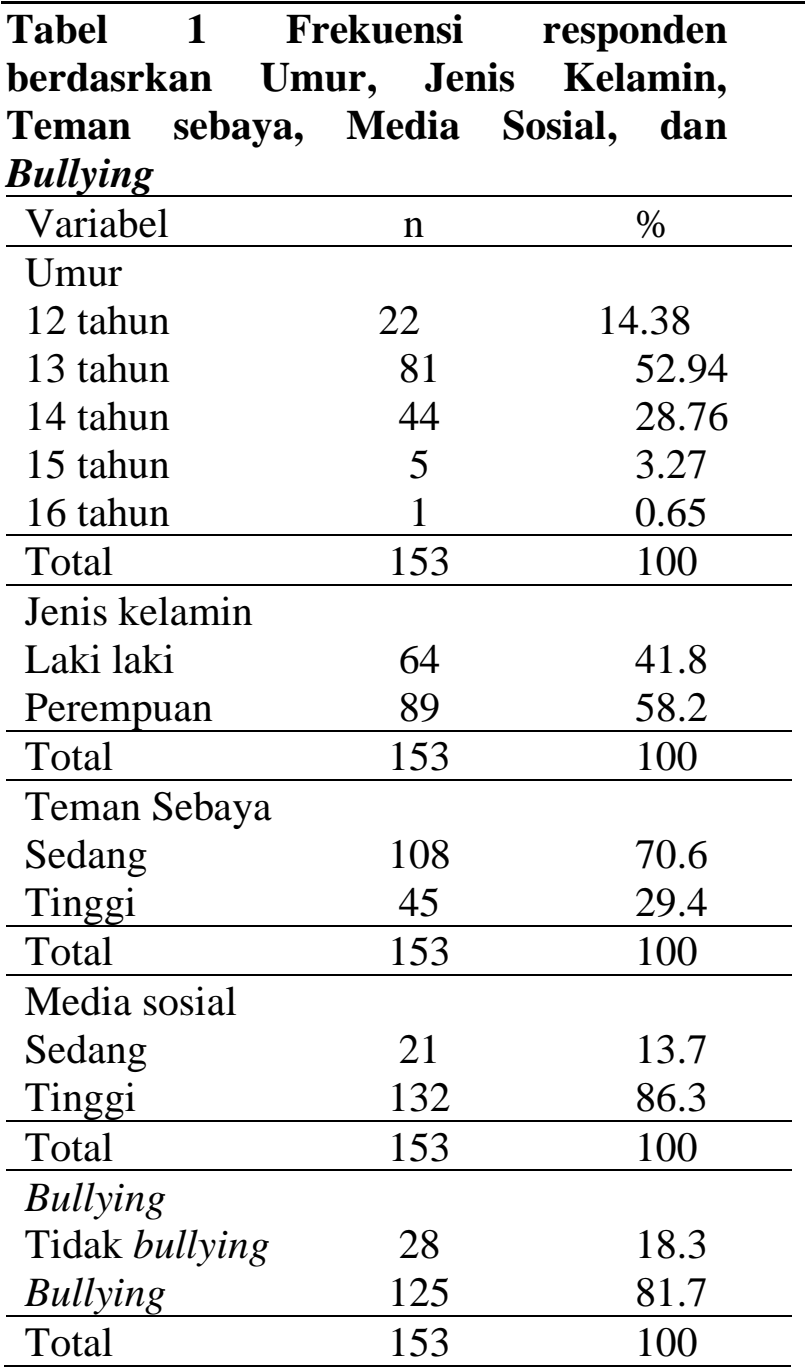

\section{Pembahasan}

\section{Hubungan Jenis Kelamin dengan Kejadian Bullying}

Hasil penelitian didapatkan bahwa sebagian besar 78 responden $(51 \%)$ yang berjenis kelamin perempuan melakukan bullying. Hal ini disebabkan oleh karena dari hasil wawancara yang dilakukan penelitipada saat observasi awal didapatkan sebagian besar siswa yang berjenis kelamin perempuan sering keluar masuk ruang BK dengan kasus bullying yang berawal dari saling mengejek, memfitnah, dan bergosip. Kemudian, berlanjut hingga adu fisik.

Menurut Fisniwati (2018) terdapat perbedaan kepribadian laki-laki dan perempuan secara rinci yaitu : 1) Laki-laki : tidak emosional, pasif, tertutup, dan sangat sedikit membutuhkan dukugan kelompok; 2) Perempuan : sangat emosional, senang dengan suasana kompetitif, aktif, terbuka,

Tabel 2 Hubungan Jenis Kelamin, teman sebaya, dan media sosial dengan Kejadian Bullying

\begin{tabular}{|c|c|c|c|c|c|c|c|}
\hline \multirow[b]{2}{*}{ Variabel } & \multicolumn{2}{|c|}{$\begin{array}{c}\text { Tidak } \\
\text { bullying }\end{array}$} & \multicolumn{2}{|c|}{ Bullying } & \multicolumn{2}{|c|}{ Jumlah } & \multirow{2}{*}{$\begin{array}{c}\text { Uji } \\
\text { statist } \\
\text { ik }\end{array}$} \\
\hline & $\mathrm{n}$ & $\%$ & $\mathrm{~N}$ & $\%$ & $\mathrm{n}$ & $\%$ & \\
\hline $\begin{array}{l}\text { Jenis } \\
\text { kelamin }\end{array}$ & & & & & & & $\begin{array}{c}\rho= \\
0.034\end{array}$ \\
\hline Laki-laki & 17 & 11.1 & 47 & 30.7 & 64 & 41.8 & \\
\hline perempuan & 11 & 7.2 & 78 & 51 & 89 & 58.2 & \\
\hline Total & 28 & 18.3 & 125 & 81.7 & 153 & 100 & \\
\hline $\begin{array}{l}\text { Teman } \\
\text { sebaya }\end{array}$ & & & & & & & $\begin{array}{c}\rho= \\
0,039\end{array}$ \\
\hline Sedang & 15 & 9.8 & 93 & 60.8 & 108 & 70.6 & \\
\hline Tinggi & 13 & 8.5 & 32 & 20.9 & 45 & 29.4 & \\
\hline Total & 28 & 18.3 & 125 & 81.7 & 153 & 100 & \\
\hline $\begin{array}{l}\text { Media } \\
\text { sosial }\end{array}$ & 8 & 5.2 & 13 & 8.5 & 21 & 13.7 & $\begin{array}{c}\rho= \\
0.028\end{array}$ \\
\hline $\begin{array}{l}\text { Sedang } \\
\text { tinggi }\end{array}$ & 20 & 13.1 & 112 & 73.2 & 132 & 86.3 & \\
\hline Total & 28 & 18.3 & 125 & 81.7 & 153 & 100 & \\
\hline
\end{tabular}

Sumber : Data primer diolah, 2020 percaya diri, dan sangat membutuhkan dukungan kelompok. Sehingga, dapat dikatakan perempuan lebih cenderung dapat melakukan bullying.

Sugiyanto (2012) menjelaskan bahwa pada usia 9-12 tahun mulai muncul tanda perkembangan identitas remaja untuk berkelompok dan menunjukkan tanda-tanda konformitas (bentuk sikap penyesuaian diri seseorang dalam masyarakat/kelompok karena dia terdorong untuk mengikuti 
kaidah- kaidah dan nilai-nilai yang sudah ada), terutama pada anak perempuan. Penelitian ini sependapat dengan penelitian yang dilakukan oleh Putri (2015) yang berjudul "Faktor-faktor yang berhubungan dengan kejadian bullying pada remaja." Menurut Putri (2015), bahwa: “ada hubungan antara jenis kelamin dengan kejadian bullying. Ketimpangan gender dalam lingkungan permainan anak sekolah dapat menyebabkan anak tumbuh dalam iklim pergaulan yang tidak sesuai dengan kecenderungan jenis kelaminnya untuk bermain dan berkelompok sesuai dengan sifat jenis kelamin bawaannya." Didukung oleh penelitian Sugmalestari (2016) yang berjudul hubungan jenis kelamin dengan perilaku bullying pada anak usia sekolah di sd muhammadiyah mlangi gamping sleman yogyakarta. Menurut Sugmalestari (2016), bahwa: "jenis kelamin lebih berperan dalam menentukan tipe bullying. Perempuan lebih cenderung melakukan tipe bullying psikologis dibandingkan laki-laki dan lakilaki lebih cenderung melakukan tipe bullying fisik dibandingkan perempuan."

\section{Hubungan teman sebaya dengan}

\section{Kejadian Bullying}

Berdasarkan hasil analisa bivariat uji hubungan menggunakan fisher's exact test diperoleh $p$ Vaule 0,039. Karena nilai $p$ Vaule $<0,005$, maka dapat dikatakan bahwa ada hubungan antara teman sebaya dengan kejadian bullying di SMP N 3 Gorontalo.

Hasil penelitian pada tabel 4.7 didapatkan bahwa sebagian besar teman sebaya dalam kategori sedang 93 responden $(60.8 \%)$ melakukan bullying. Menurut Septiyuni (2015), bahwa: "Perilaku bullying merupakan tindakan delikuen remaja yang secara sosiologis disebabkan oleh pergaulan remaja dengan lingkungan sosialnya yang cenderung dalam frekuensi usia yang sama. Memiliki beberapa persamaan adalah salah satu kriteria dalam pembentukan kelompok sebaya. Tidak jarang seorang remaja akan lebih percaya terhadap informasi yang disampaikan oleh teman sebayanyanya daripada informasi yang disampaikan oleh orang tuanya (Suryanita, 2016).

Adanya dukungan teman sebaya secara tidak langsung memberitahukan kepada anak tersebut bahwa tindakan yang ia lakukan adalah hal yang benar dan menunjukkan bahwa banyak orang yang berpihak padanya. Sehingga, tidak menutup kemungkinan anak tersebut bisa melakukan hal yang lebih besar lagi jika mendapat dukungan dari teman sebayanya. Penelitian yang dilakukan pada kelompok teman sebaya didapatkan bahwa penolakan dari teman sebaya dapat menimbulkan perasaan kesepian dan dimusuhi, sehingga dapat 
mempengaruhi kesehatan mental dan menimbulkan masalah kriminal. Teman sebaya juga dapat mengenalkan kepada alkohol, perilaku abnormal dan kenakalankenalan lainnya (Santrock, 2017).

Penelitian ini sependapat dengan penelitian yang dilakukan oleh Jannatung (2015) dengan judul "Faktor - faktor penyebab terjadinya perilaku bullying di sman 2 barru." Menurut Jannatung (2018), bahwa: "ada hubungan antara teman sebaya dengan kejadian bullying. Pada penelitiannya, dijelaskan bahwa pada masanya remaja memiliki keinginan untuk tidak lagi terlalu bergantung pada keluarganya dan mulai mencari dukungan dan rasa aman dari kelompok sebayanya." Didukung juga oleh penelitian Budimansyah (2015). Menurut Budimansyah (2015), bahwa: "Korelasi antara kelompok teman sebaya dan perilaku bullying adalah positif dan signifikan dengan nilai koefisien korelasi sebesar 0,360 dan nilai $\rho<0,05$ sehingga kelompok teman sebaya berpengaruh terhadap terjadinya perilaku bullying siswa di sekolah, dapat diterima dan telah diuji keberartiannya.

\section{Hubungan media sosial dengan Kejadian} Bullying

Berdasarkan hasil analisa bivariat uji hubungan menggunakan fisher's exact test diperoleh $p$ Vaule 0,028 . Karena nilai $p$ Vaule < 0,005, maka dapat dikatakan bahwa ada hubungan antara media sosial dengan kejadian bullying di SMP N 3 Gorontalo.

Hasil penelitian pada tabel 4.8 didapatkan bahwa sebagian besar media sosial dalam kategori tinggi 112 responden (73.2\%) melakukan bullying. Menurut Pearce (2015) media sosial merupakan sebuah media daring yang penggunanya dengan mudah berpatisipasi, berbagi, dan membuat isi meliputi blog, jejaring sosial, forum, dan dunia virtual. Dampak yang sering terjadi adalah bullying. Perilaku ini akan menjadi kebiasaan dan mengakibatkan ketidakseimbangan kekuasaan sosial dan fisik. Bagi anak yang menonton TV maupun tontonan yang didapatkan di media sosial lainnya dengan rating umur yang tidak sesuai dapat membuat agresivitas mereka dalam peningkatan tindakan bullying pada anak.

Kalangan remaja yang mempunyai media sosial biasanya memposting tentang kegiatan pribadinya, curhatannya, serta fotofoto bersama teman. Dalam media sosial siapapun dapat dengan bebas berkomentar serta menyalurkan pendapatnya tanpa rasa khawatir. Hal ini dikarenakan dalam internet khususnya media sosial sangat mudah memalsukan jati diri atau melakukan kejahatan. Padahal 
dalam perkembangannya di sekolah, remaja

berusaha mencari identitasnya dengan

bergaul bersama teman sebayanya. Namun saat ini seringkali remaja beranggapan bahwa semakin aktif dirinya di media sosial maka mereka akan semakin dianggap keren dan gaul. Sedangkan remaja yang tidak mempunyai media sosial biasanya dianggap kuno atau ketinggalan jaman dan kurang bergaul (Nurwati, 2016).

Penelitian ini sependapat dengan penelitian yang dilakukan oleh Sufriani (2018) yang berjudul "Faktor yang mempengaruhi bullying pada anak usia sekolah di sekolah dasar." Menurut Sufriani (2018), bahwa: "Ada hubungan antara media sosial dengan kejadian bullying. Dalam penelitiannya, Sufriani menyatakan bahwa tindakan bullying lebih banyak berasal dari tontonan-tontonan kekerasan yang di dapatkan dari media sosial maupun media cetak.

Televisi dan media cetak membentuk pola perilaku bullying dari segi tayangan yang mereka tampilkan." Di dukung juga oleh penelitian Naning (2017) dengan judul "Pengaruh intensitas penggunaan sosial media dan penerimaan teman sebaya terhadap perilaku bullying siswa. Menurut Naning (2017), bahwa: "Hasil intensitas penggunaan sosial media berpengaruh secara signifikan terhadap bullying yang terjadi. Semakin tinggi tingkat penggunaan media sosial semakin tinggi pula perilaku bullying.".

\section{Simpulan}

Kejadian bullying di SMP N 3 Gorontalo masih tinggi dengan presentasi $81.7 \%$ (125 responden). Dalam penelitian ini juga didapatkan ada hubungan antara jenis kelamin, teman sebaya, dan media sosisal dengan kejadian bullying di SMA N 3 Gorontalo.

\section{Daftar Pustaka}

Ariobimo, N. 2010. Bullying : Mengatasi Kekerasan Disekolah Dan Lingkungan Sekitar Anak. Jakarta : PT Grasindo

Banthayo.Id, Gorontalo. 2019. Pelajar SMP Di Gorontalo Diduga Dianiaya Senior Gara-Gara Pacarnya. www.Kumparan.Com

Cornell et al. 2016. The Authoritative school climate survey and the schol climate bullying survey. Journal of Virgina University 2(1)

Darmawan, 2017. Fenomena Bullying (Perisakan) Di Lingkungan Sekolah. Jurnal Kependidikan 1(2) 253-262

Husaini, A. N. 2015. Hubungan Antara Presepsi Jenis Pola Asuh Orang Tua Terhadap Resiko Perilaku Bullying Siswa Di SMA Triguna Utama. Skripsi. Kedokteran Dan Ilmu Kesehatan UIN Syarif Hidayatullah

Hymel, S. Et Al. 2015. Four Decades Of

Research On School Bullying: An Introduction. American Psychologist, 70(4), 293-299

Greogory et al. 2017. Teori Kepribadian. Jakarta : Salemba Humanika 
Imron. 2011. Metode Penelitian Kuantitatif, Kualitatif Dan $R \& D$. Bandung: Alfabeta.

Jannatung, A. 2018. Faktor-Faktor Penyebab Terjadinya Bullying Di Sma

2 Baru. Skripsi. Program Sarjana Universitas Hasanuddin

Juvonen, J. (2018). Bullying In School And

Online Contexts: Social Dominance, Bynstander Compliance, And Emotional Pain Of Victim. Psyarxiv Larasati, A. 2016. Kecenderungan Perilaku Cyberbullying Ditinjau Dari Trait Dalam Pendekatan Big-Five Personality Pada Siswa Sekolah Menegah Atas Negeri Kota Yogyakarta. Jurnal psikologi integratif 4(2) 161-182

Kusumawati, F. 2010. Buku Ajar Keperawatan Jiwa. Jakarta : Salemba Medika

Notoatmojo. 2012. Metode Penelitian Kesehatan. Jakarta: Rineka Cipta.

Nursalam. 2013. Metode Penelitian Ilmu

Keperawatan: Pendekatan Praktis Edisi 3. Jakarta: Salemba Medika.

Patchin, J. 2012. Cyberbullying Prevention And Response: Exper Perspective. Routledge

Provis, S. A. 2012. Bullying (1950- 2010):

The Bully And The Bullie.

Disesertation. School Of Education

Puluhulawa, E. 2018. Hubungan

Bullying Dengan Prestasi Belajar Siswa Smp Negeri 6 Kota Gorontalo. Skripsi. Program Sarjana Universitas Negeri Gorontalo

Putri, H. 2015. Faktor-Faktor Yang

Berhubungan Dengan Perilaku Bullying Pada Remaja. Journal of Medical 2(2)1149-1159
Qodar, N. 2015. Survei ICRW : 84\% Anak Indonesia

Alami Kekerasan Disekolah. Liputan 6.Com

Qomariyah, A. 2011. Perilaku Penggunaan Internet Pada Kalangan Remaja Di Perkotaan. Surabaya: Universitas Airlangga

Republika Online. 2014. Aduan Bullying Tertinggi.

Www.Google.Co.Id/Amp/M. $\underline{\text { Republika.Co.Id/Amp_Versio }}$ $\underline{\mathrm{n} / \mathrm{Ndh} 4 \mathrm{sp}}$

Riyanto, A. 2011. Pengolahan Dan Analisis Data Kesehatan. Yogyakarta: Medikal Book.

Sripurwaningsih, I. 2017. Hubungan

Perundungan (Bullying) Dengan

Kepercayaan Diri Siswa Kelas X Sma

Muhammadiyah1

Karanganyar. Skripsi. Program Sarjana

Institut Agama Islam Negeri Surakarta Sugiyono. 2017. Metode Penelitian Kuantitatif, Kualitatif Dan R\&D. Bandung: Alfabeta.

Sugmalestari, A. 2016. Hubungan Jenis Kelamin Dengan Perilaku Bullying Pada Anak Usia Sekolah Di SD Muhammadiyah Mlangi Gamping Sleman. Skripsi. Program Sarjana Universitas Aisyiyah Yogyakarta

Wardhana, K. 2015. Buku Panduan Melawan Bullying. Jakarta:

Sudahdong.Com

Wardiati, E. 2018. Pengaruh Bullying Terhadap Moralitas Siswa Pada Smp Negeri 1 Darul Hikmah Kabupaten Aceh Jaya. Skripsi. Program Sarjana Universitas Islam Negeri Ar-Rainiry Darussalam Banda Aceh 
WHO (World Health Organization). 2010.

Prevention Of Bullying-Related

Morbidity And Mortality: A Call For

Public Health Policies

2014. Heatth Topic :Adotescents

Health..Who.Int/En/

Wiyani, N.A. 2012. Save Our Children

From School Bullying. AR-RUZZ

MEDIA: Jogjakarta

Yunita, B. 2019. Faktor-Faktor Yang Mempengaruhi Perilaku Bullying Pada Remaja Awal. Nursing News, 4(1).

Zakiyah, E. 2017. Faktor Yang Mempengaruhi Remaja Dalam

Melakukan Bullying Journal Unpad 4(2): 129- 389 